\title{
A millennium of variable ice flow recorded by the Ross Ice Shelf, Antarctica
}

\author{
M. A. Fahnestock, ${ }^{1}$ T. A. Scambos,${ }^{2}$ R. A. Bindschadler,${ }^{3}$ G. Kvaran ${ }^{2}$ \\ ${ }^{1}$ Earth System Science Interdisciplinary Center, University of Maryland, College Park, Maryland 20742-2465, U.S.A. \\ ${ }^{2}$ National Snow and Ice Data Center, CIRES, University of Colorado, Boulder, Colorado 80309-0449, U.S.A. \\ ${ }^{3}$ NASA Goddard Space Flight Center, Code 971, Greenbelt, Maryland 20771, U.S.A.
}

\begin{abstract}
An enhanced composite Advanced Very High Resolution Radiometer (AVHRR) image is used to map flow stripes and rifts across the Ross Ice Shelf, Antarctica. The patterns of these flow-related features reveal a history of discharge variations from the ice streams feeding the eastern part of the shelf. The most profound variations are visible in the track of rifts downstream of Crary Ice Rise, flow-stripe bends to the west of this ice rise and adjacent to Steershead ice rise, and changes in the northern margin of Ice Stream B. The track of rifts downstream of Crary Ice Rise indicates that the ice rise has existed for at least 700 years. The character of this track changes about $350 \mathrm{~km}$ downstream, indicating a rearrangement of flow patterns about 550 years ago. The large bulge in the flow stripes to the west of Crary Ice Rise is shown in detail, with bent flow stripes extending for several hundred kilometers along flow; this feature formed from the south, possibly due to a change in the discharge of Ice Stream A. The AVHRR image documents a complex history associated with the shutdown of Ice Stream C, with changes in the margins of Ice Stream C and the northern margin of Ice Stream B, and the grounding of Steershead ice rise with an associated bending and truncation of flow stripes. Landsat imagery shows a region that appears to be actively extending just downstream of the ice rise, as the shelf continues to respond to recent changes in ice-stream discharge. We present a four-stage flow history which accounts for the features preserved in the ice shelf.
\end{abstract}

\section{INTRODUCTION}

Ice sheets are known to change on many time-scales. One area where significant changes have been documented is West Antarctica, particularly the region where fast-moving ice streams drain the interior ice sheet into the Ross Ice Shelf (Alley and Whillans, 1991). Recent studies in that area have revealed changes in both the flow speed and margin position of streams on a decadal time-scale (Bindschadler and Vornberger, 1998; Echelmeyer and Harrison, 1999). Stagnant former ice streams have been identified, illustrating changes in flux and configuration of the ice streams on century time-scales (Shabtaie and Bentley, 1987). On millennial time-scales, the West Antarctic ice sheet has retreated significantly, losing up to two-thirds of its mass over the 12000 years since the end of the Last Glacial Maximum (LGM) (Bindschadler, 1998a; Hughes, 1998).

The retreat from the LGM in this area may be ongoing, although measuring its rate over the short period of historical record is difficult. Evidence that ice-stream discharge patterns from the ice sheet are rapidly varying further complicates this task. However, knowledge of the record of change over longer time-scales would improve our understanding of the present and possible future behavior of the ice sheet.

One useful method for recognizing changes in the flow pattern of ice sheets has been the interpretation of flow-related features in satellite imagery of the ice sheets (a review appears in Bindschadler, 1998b). This type of interpretation is perhaps even more effective over ice shelves, where most flow-related features are passively advected by the floating ice. Much of the original large-area image interpretation showing the spatial extent of the ice streams in West Antarctica was based on moderate-resolution imagery collected by the Advanced Very High Resolution Radiometer (AVHRR) from U.S. National Oceanic and Atmospheric Administration polar-orbiting weather satellites (Bindschadler and Vornberger, 1990). Detailed analysis drew more heavily on higher-resolution imagers such as Landsat and Système probatoire pour l'observation de la terre (SPOT) (Scambos and Bindschadler, 1991; Merry and Whillans, 1993; Ferrigno and others, 1994).

Detailed satellite-based studies on the Ross Ice Shelf have been limited to individual Landsat scenes by cost and by the lack of coverage south of $82^{\circ} \mathrm{S}$. In this paper, we present an analysis of flow patterns based on a new composite AVHRR image, enhanced to show increases in subtle topographic features over the entire ice shelf. The comprehensive view afforded by this improved imagery allows us to integrate earlier observations, including those by the Ross Ice Shelf Geophysical and Glaciological Survey (RIGGS) (Bentley, 1984; Robertson and Bentley, 1984; Thomas and others, 1984) field program and subsequent analyses of this dataset. Our analysis places this previous work in the context of additional morphological evidence. Using this additional evidence, we present a scenario for the evolution of ice-stream flow into the Ross Ice Shelf. 


\section{COMPOSITE IMAGE OF THE ROSS ICE SHELF}

Figure 1 shows the entire $525000 \mathrm{~km}^{2}$ Ross Ice Shelf in a datacumulated AVHRR image composite. Data cumulation is a processing technique which combines multiple images of the same area, each having similar imaging and illumination geometry, using accurate sub-pixel-scale co-registration (see Scambos and others, 1999). The resulting composite image has enhanced spatial and radiometric resolution. The need for similar illumination and imaging geometry in each component scene mandates that the image series be acquired from near-repeat orbits over a period of a few weeks. For this composite, 15 images from November and December 1992 were selected on the basis of their hour of acquisition (constraining sun azimuth and viewing geometry), image data quality and per cent clear-sky coverage. A synthesized "channel" consisting of the first principal component of channels 1 and 2 (550-900 and 730-1100 nm, respectively) was used in the compositing. This reduces noise, adds radiometric sensitivity, minimizes the effect of grain-size variations, and provides the commonly varying signal in the two channels correlated to surface slope (Orheim and Lucchitta, 1988). The Appendix contains additional details of the processing and final image characteristics.

The final composite has approximately a factor of two improvement in spatial resolution and a nearly four-fold improvement in radiometry over individual scenes. It reveals a number of features not identified in earlier imagery. The solar illumination direction (azimuth) for the main composite was chosen to match that of most Landsat thematic mapper (TM) imagery of the shelf for intercomparison. However, features parallel to the solar azimuth (to the lower right in Fig. 1) are subdued relative to their appearance in sun-crossing images. A second composite, consisting of 10 images from the same period with a more southerly solar azimuth, was used for the area bounded by Crary Ice Rise, Steershead ice rise and Ice Stream C (see Fig. 7, shown later) to alleviate this problem and enhance additional features.

\section{DESGRIPTION OF INTERPRETED FEATURES}

Many of the features in Figure 1 can be used in the interpret-

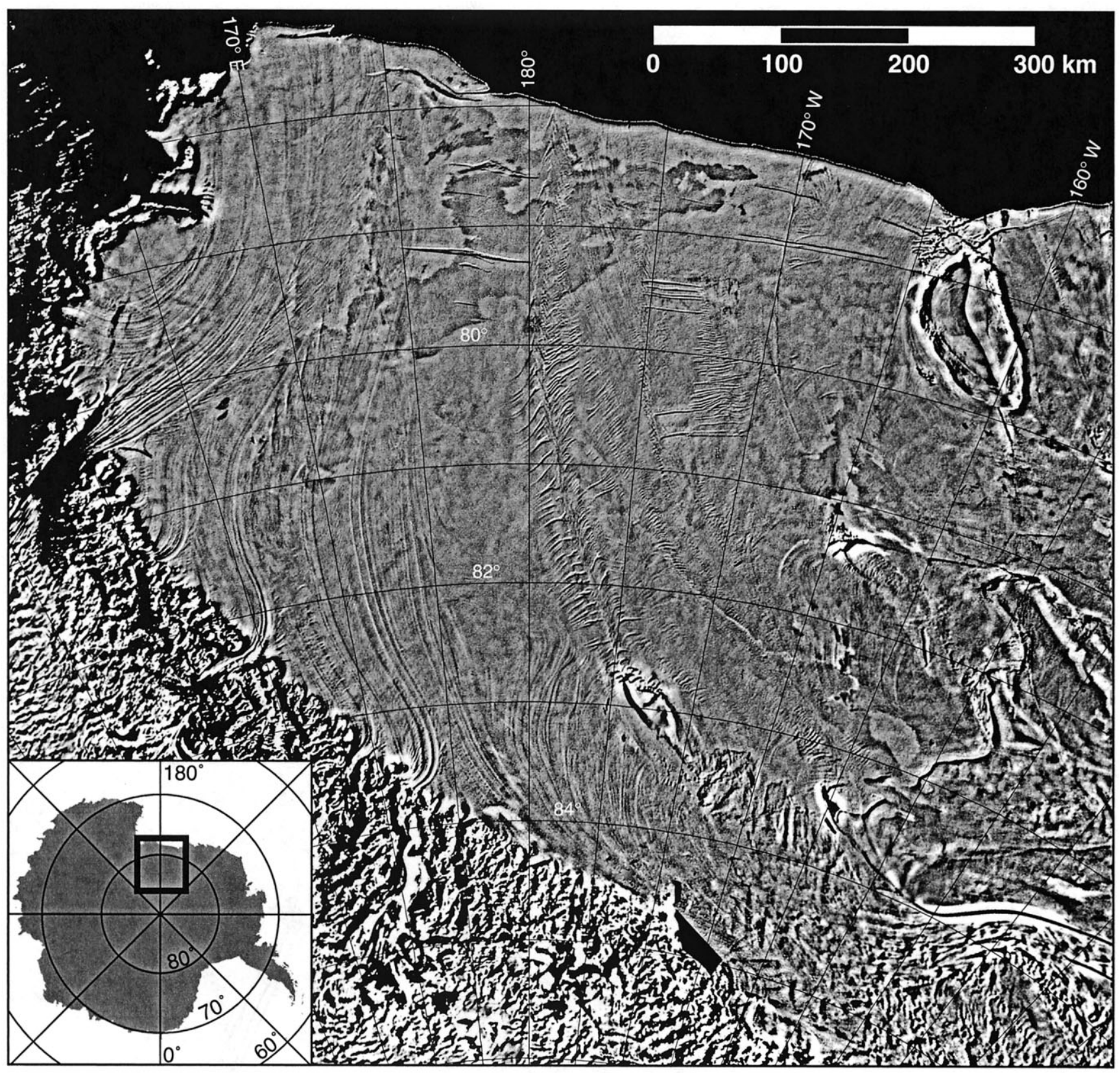

Fig. 1. Enhanced AVHRR image composite of the Ross Ice Shelf, showing many features related to the ice-flow history from outlet glaciers and ice streams. Details of the image composite production are discussed in the text and Appendix. 


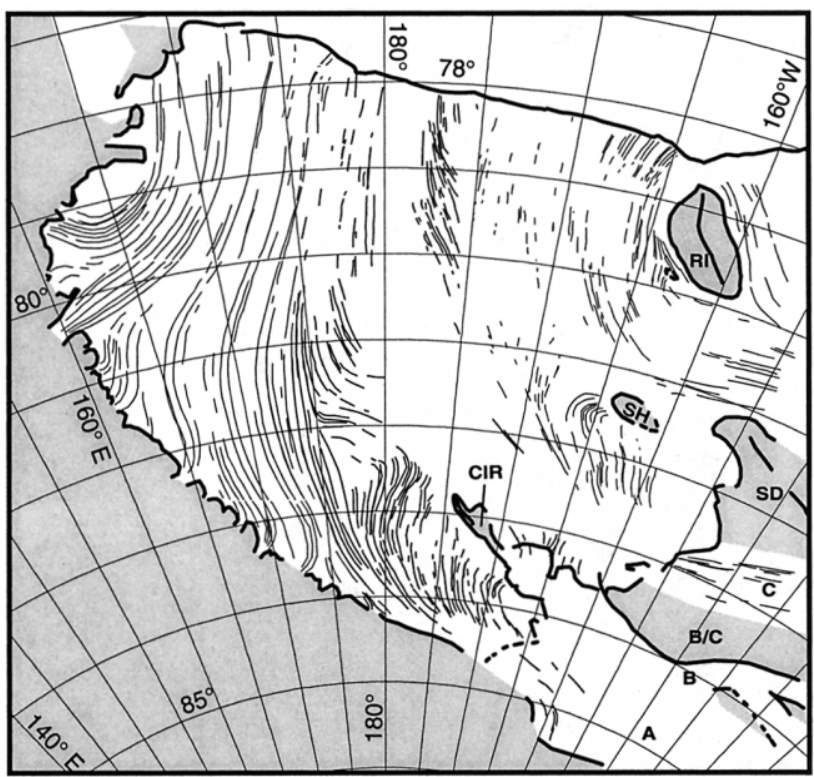

a

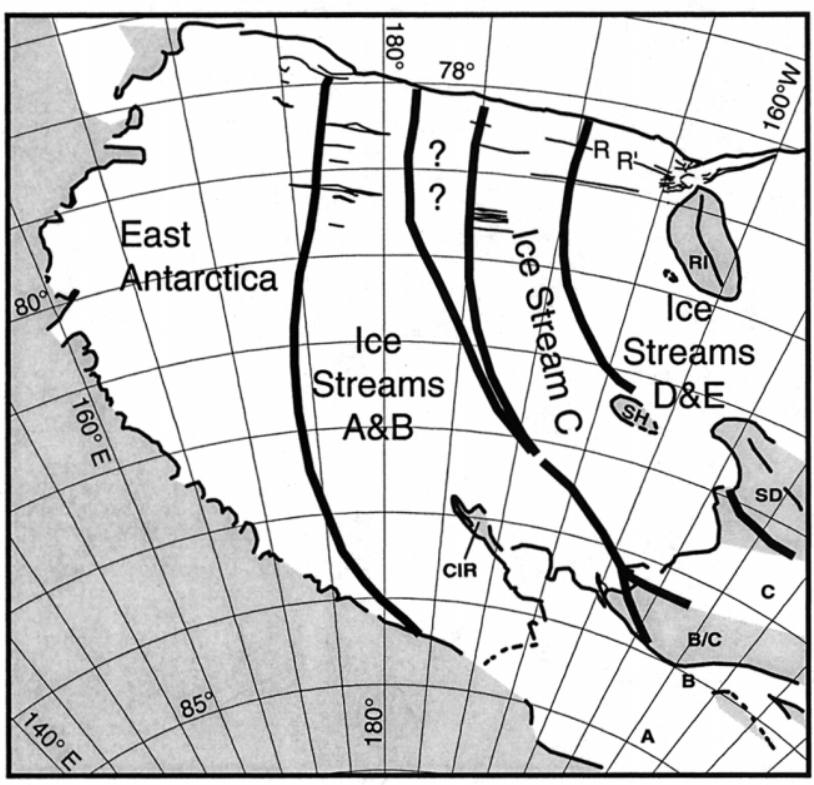

c

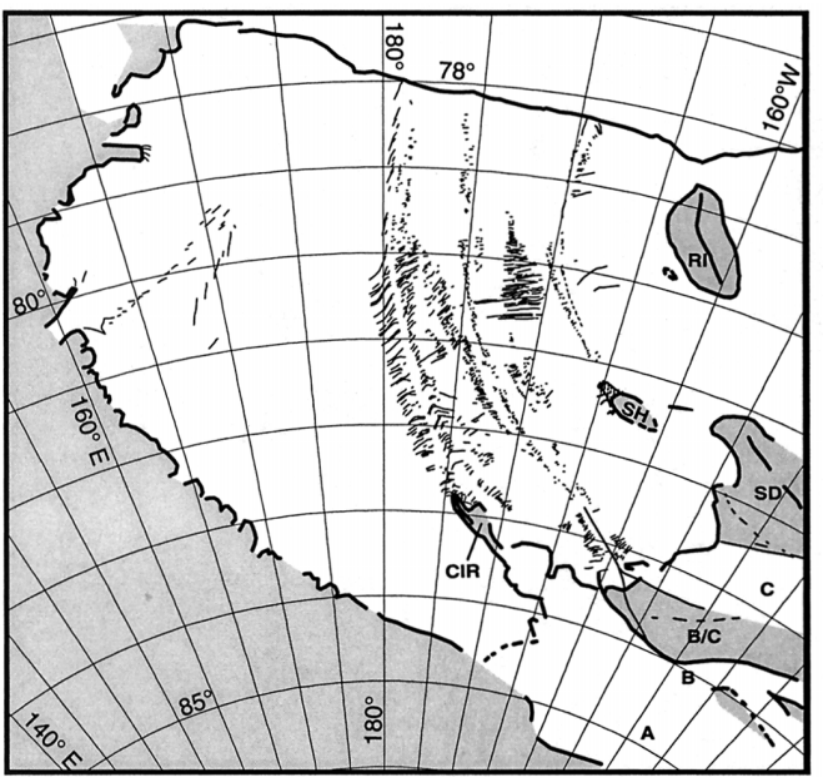

b

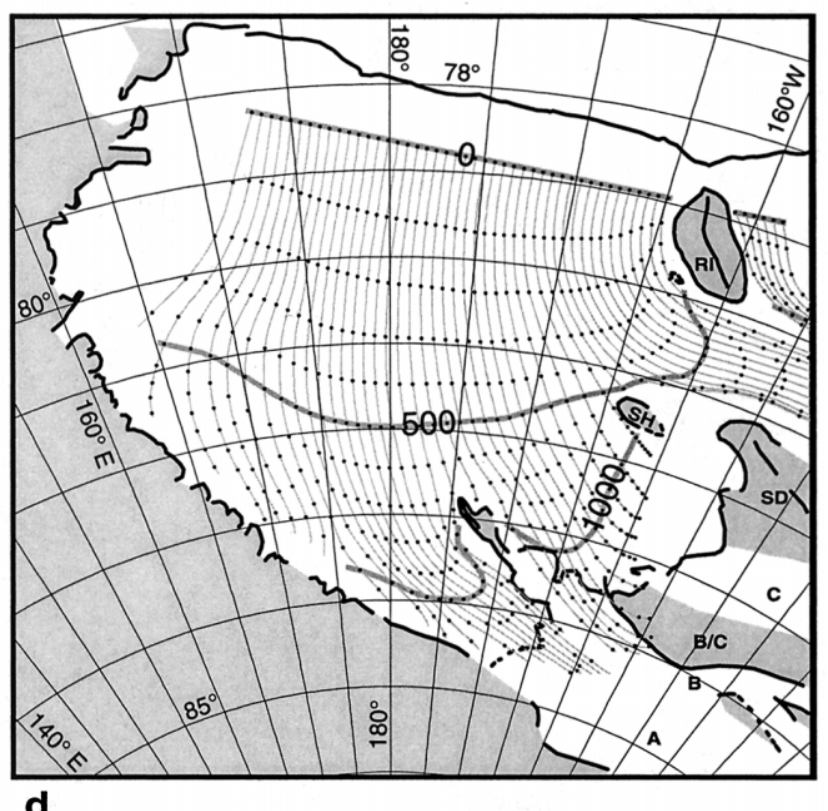

Fig. 2. (a) Flow stripes and (b) rifts and crevasse series mapped from the enhanced image composite of Figure 1. Note the preponderance of these features in the ice from Ice Streams A-C. (c) Provenance of the ice in the Ross Ice Shelf as determined from tracing the tracks of flow boundaries, including formerly active margins of Ice Stream C. Also shown are the sets of ice-front-parallel rifts, visible in Figure 1, which are likely sites of future calving (the rifts labeled $R$ and $R^{\prime}$ are discussed in the text). (d) Flowlines and 100 year particle motion dots illustrate the RIGGS measured velocity field. Heavy grey 500 and 1000 year contours show the time required for ice to reach the 0 year contour line near the ice front in the RIGGS flow field. In all four frames a heavy line showes the locations of the grounding line, the ice front, the ice divides on Siple Dome and Roosevelt Island, and active shear margins. Roosevelt Island (RI), Steershead ice rise (SH), Crary Ice Rise (CIR), Siple Dome (SD) and ridge B/C are labeled, as are Ice Streams $A-C$.

ation of flow history. Similar interpretations have been applied to satellite imagery of ice streams and ice shelves (see, e.g., Crabtree and Doake, 1980; Ferrigno and others, 1994; Hambrey and Dowdeswell, 1994); each of these works has used slightly different terminology when describing these features. Figure 2 summarizes the features we use in our interpretation, as well as the flow field as measured during the RIGGS program (Thomas and others, 1984). The mapped features are manifest in the surface relief of the ice shelf, identifiable by their pattern and morphology, and by upstream tracing to areas of ongoing formation. They include flow stripes, crevasse or rift sets formerly associated with grounded ice, and ice-stream margin "scars", seen as faint streaks of rougher surface on the shelf that con- nect upflow to existing or former shear margins. Interpretative use of each type of feature depends on the flow processes responsible for its generation.

Flow stripes are surface topographic ridges or troughs with few-meter-scale relief, hundreds of meters to a few kilometers wide and tens to hundreds of kilometers long. They form in outlet glaciers and ice streams. Merry and Whillans (1993) use the term "flow traces" for these features and provide an example of the generation of a trace near the head of Ice Stream B. Crabtree and Doake (1980) term these features "lineations", one of two types of features which are likely parallel to current flow and thus represent flowlines on the Filchner-Ronne Ice Shelf system. Ferrigno and others (1994) use the term "flow bands" in their discussion of Landsat 
imagery of the ice streams flowing into the Ross Ice Shelf. Dowdeswell and McIntyre (1987) identify "apparent flowlines" of unknown origin in a Landsat image of Byrd Glacier. Casassa and Turner (1991) use the term "flow stripes" for features in AVHRR imagery of the Ross Ice Shelf. Hambrey and Dowdeswell (1994) use the term "foliation" because the features appear to be the surface expression of a three-dimensional structure observed on the ground on another ice shelf. These investigators point out that the structure may be rotated relative to the current ice-flow direction. In this paper, we will use the term "flow stripe" because it emphasizes the fact that these features serve as flow indicators from a localized source, without implying a specific origin, a relationship to the modern iceflow field or a tie to unknown internal structure in the ice.

Various generation mechanisms have been postulated for flow stripes, in general related to localized high shear strain rates in ice streams near their onset areas and around "sticky spots" (e.g. Merry and Whillans, 1993; Gudmundsson, 1996). Their persistence on the ice shelf can be explained by low transverse spreading rates and the existence of matching basal topography with larger amplitude (Casassa and Whillans, 1994). In a steady-state system, flow stripes would be aligned with the flow field throughout the ice shelf, and therefore parallel to present-day flowlines. Temporal variation in flow direction results in flow stripes that cross the flow field. Once misaligned, flow stripes can experience progressive rotation. Figure 2a shows flow stripes on the Ross Ice Shelf identified in the data-cumulated AVHRR image. Much of the flow interpretation throughout this paper is based on their structure. We note that at present the flow stripes are nearly parallel to flow at the grounding line (or just upstream of it). We will assume this to be the case in the past as well, although the situation may have been more complex for Ice Streams $\mathrm{A}$ and $\mathrm{B}$, as discussed later.

The pattern of crevasses and rifts in the ice shelf, as identified in the imagery (Fig. 2b), will also be used for flow interpretation. The distinction between crevasses and rifts we use is one of scale: rifts are large enough to penetrate the entire shelf thickness. We determine this distinction on the basis of comparison with known rifts, such as near Crary Ice Rise. The resolution of the AVHRR image is such that most of the identifiable individual crevasses in the ice shelf are rifts. These large features are most often formed at right angles to the ice-flow direction, where ice moves past a grounded region. Like flow stripes, crevasses and rifts rotate when their orientation is not aligned with the direction of shear in the flow field. Their downstream evolution provides clues to the flow field experienced by the crevasse or rift sequence. If the stress state changes, crevasse length or orientation can change, or formation can stop altogether.

Another source of crevasses on the ice shelf is the downstream trajectories of ice-stream margins (Fig. 2b). These trajectories are formed by densely spaced crevasses that are not individually resolvable in the AVHRR image. They are likely to be buried, but still appear as lines of increased surface roughness. Their initial identification was made by tracing patterns of surface roughness upstream to active margins in grounded ice using Landsat imagery (see Ferrigno and others, 1994).

A separate class of rifts is mapped in Figure 2c, along with ice provenance boundaries that will be discussed in the next section. These rifts are formed in longitudinal tension parallel to the ice-shelf front, possibly by a combination of tidal flexure and increasing longitudinal tension as the ice front is approached. They lengthen with time and determine likely sites of iceberg formation as the ice moves nearer the shelf front. The long rifts near the ice front in the eastern Ross Ice Shelf formed after 1983, and have been observed to lengthen in more recent satellite imagery. In a 1996 AVHRR image, the two rifts closest to the ice front ( $\mathrm{R}$ and $\mathrm{R}^{\prime}$ in Fig. 2c) have extended and intersected. The ice front immediately to the west of Roosevelt Island is likely to be the source of the next large iceberg from this area. In several instances, sets of these ice-front-parallel rifts have ends that are aligned along flow. These sets end at a flow stripe or flow-related boundary that seems to limit their propagation, possibly because the bounding feature is composed of softer ice that does not allow for crack propagation.

Mottling and large irregular patches on the ice surface mark variations in reflectivity due to snow wetness or surface frost (e.g. across the upper left part of the shelf in Fig. 1). These are transient weather-related features that are not pertinent to flow evolution.

\section{PROVENANGE OF THE ROSS ICE SHELF}

The ice stream or glacier which was the source for each portion of the Ross Ice Shelf can usually be determined by tracing the trajectories of the margins of each input feature across the ice shelf. This tracing is guided primarily by flow stripes and the downstream record of shear margins. Figure 2c maps the separate provenances of the Ross Ice Shelf determined in this manner.

The western third of the ice shelf is fed by East Antarctic ice entering through the Transantarctic Mountains, while the eastern two-thirds is fed by West Antarctic ice entering through Ice Streams A-E. Despite clear evidence of several changes in flux and configuration in Figure 2, all of the ice in the West Antarctic part of the shelf can be linked to existing ice streams, with one exception between the Ice Stream $\mathrm{B}$ and $\mathrm{C}$ provenance regions (labeled "??" in Fig. 2c). The possible sources of the ice within this area are discussed in a later section. Note also that the provenance boundary for Ice Stream $\mathrm{B}$ begins not at its current shear margin but along a faint trace on the slow-moving ice of ridge $\mathrm{B} / \mathrm{C}$ which represents a previously unidentified former margin.

Provenance provides a convenient basis for the discussion of flow history. Flow-stripe structure and crevasse evolution within the ice from one stream records the history of flow within that ice stream and within the shelfward extension of that ice, whereas a misalignment of a provenance boundary with current flow direction indicates a shift in the relative discharges of adjacent streams.

Figure 2d shows flowlines determined from the velocity field measured by RIGGS, and markers that represent 100 year motions along these flowlines (calculated from an arbitrary line drawn transverse to flow near the ice front and propagated upstream). In general, the provenance boundaries align with RIGGS flowlines, suggesting an absence of dramatic changes in relative ice discharge from East and West Antarctica (Bentley and others, 1979), but detailed analyses of individual discharge units indicate that radical changes between several neighboring West Antarctic ice streams are recorded.

We use the 100 year markers to estimate the time it would take for the ice to traverse any specified distance along the shelf. This is an approximation, and the assump- 
tion strictly holds only if the ice shelf has been in equilibrium throughout its recorded history. While this paper shows that this has not been the case everywhere, the RIGGS velocity field is used judiciously for estimating the timing of changes in flow patterns. In the RIGGS flow field, the time required for a particle to travel from the presentday grounding line to the calving front ranges from 500 years in the easternmost corner of the ice shelf near Roosevelt Island to 1300 years at the southernmost edge of the ice shelf where Ice Streams A and B enter. The visualization of the flow field in Figure 2d is also useful for describing the current strain rates experienced by the ice.

Some immediate generalization can be made based on the data-cumulated image and Figure 2. Flow stripes (Fig. 2a) are more continuous on the western side of the ice shelf, i.e. that part fed by East Antarctic glaciers descending through the Transantarctic Mountains. By contrast, the eastern shelf, fed by West Antarctic ice streams, contains discontinuous and distorted flow stripes, particularly in the area fed by Ice Streams A-C. The overwhelming majority of rifts also occur in the ice discharged from these three ice streams (Fig. 2b). In the detailed analysis to follow, the millennial-scale stability of the western shelf is demonstrated, while over this same period Ice Streams A-C have displayed major flow variability.

\section{FLOW HISTORY OF EAST ANTARCTIC GLACIERS}

Earlier investigations showed that "flowlines" connecting reflection features correlated between cross-flow radar profiles had similar trajectories to RIGGS-calculated flowlines for ice originating in East Antarctica (Bentley and others, 1979; Neal, 1979; Jezek, 1984). These investigators concluded that ice discharge from the large glaciers flowing through the Transantarctic Mountains had been constant. A comparison of the flow stripes in the data-cumulated AVHRR image with the RIGGS flowlines (Fig. 3) leads to the same conclusion. The correspondence between the measured flow field and the flow stripes suggests that this part of the ice shelf has maintained a near-equilibrium condition for at least the last millennium. Close agreement is present in most areas, but the stripes in the southeastern part of the figure show less curvature than the flowlines in this region. This is likely a real effect, representing a response to changes in ice flow to the east.

\section{FLOW HISTORY OF ICE STREAMS D AND E}

In Figure 1, the area around Roosevelt Island has the appearance of a part of the ice shelf with a simple, steady flow history. A closer look at the flow-stripe patterns shows indications of variation. Figure 4 shows a discordance between the flow stripes and RIGGS flowlines that is greatest in the area southwest of the island. Here the flow stripes and flowlines diverge by as much as $20^{\circ}$ (the area labeled A in Fig. 4). Between this point and the island there is a small grounded area, shown as a dashed thick line in the figure. The flow stripes near the grounded area are distorted by flow around it; the downstream extent of this disturbance is short, implying that this area grounded recently.

We cannot directly compare the flow stripes around this feature with the RIGGS flowlines that are in the figure, because the scale of the feature is small relative to the dis-

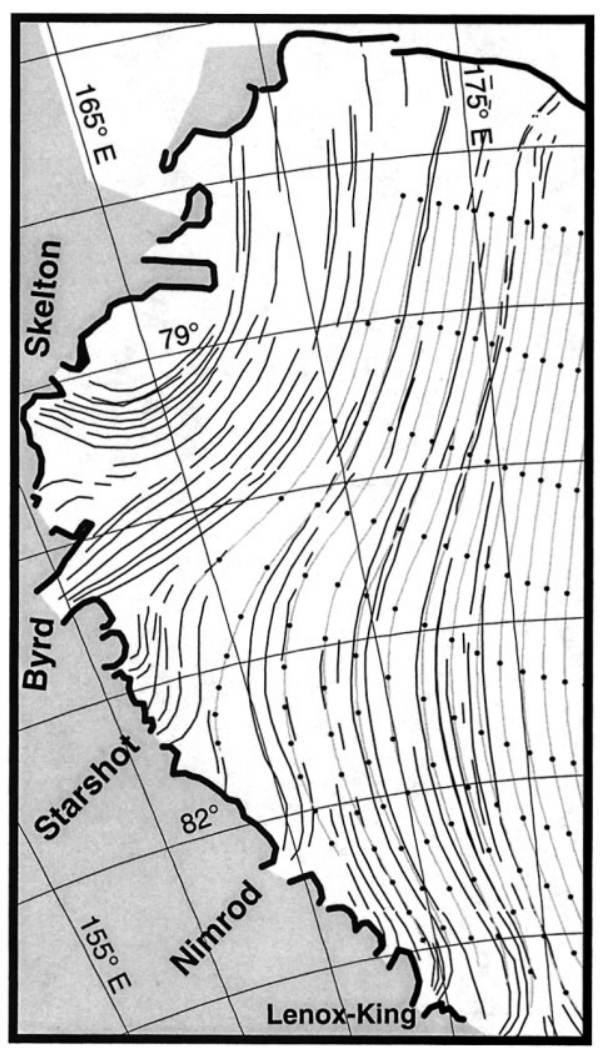

Fig. 3. Western Ross Ice Shelfflow stripes and flowlines calculated from RIGGS flow and strain measurements. Note the near-parallel nature of the flow stripes ( a record of past flow) and the RIGGS flowlines.

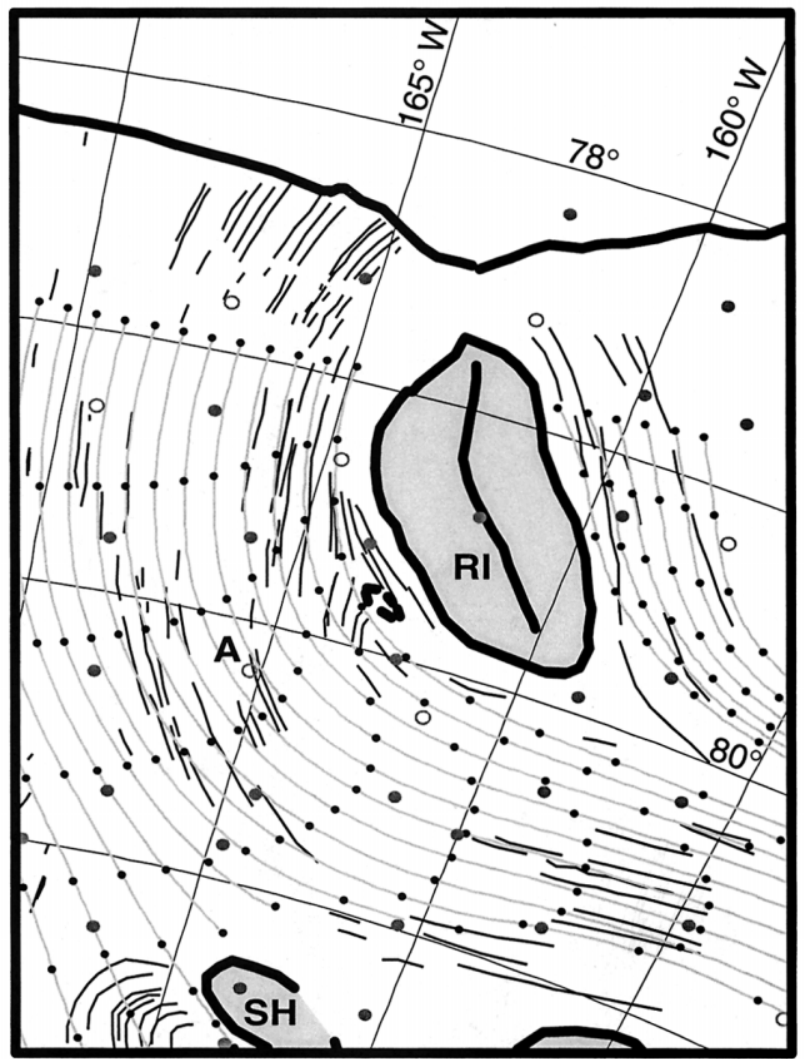

Fig. 4. Flow stripes in ice from Ice Streams $D$ and $E$ and the RIGGS flowlines around Roosevelt Island (RI). Note the discrepancy between these two flow indicators in the area marked $A$. The large open circles are sites where the RIGGS flow field was directly measured; the large grey filled circles identify RIGGS sites to which the ice motion was interpolated. Steershead ice rise (SH) is labeled. 
tance between the RIGGS stations where velocity was measured. In addition, measured RIGGS velocities are sparse in this area. At other RIGGS stations, velocities were interpolated from the measured station strain rates (Thomas and others, 1984). Figure 4 distinguishes RIGGS stations of each type. In areas where the gaps between measured velocities are just one or two stations, and the strain rates vary smoothly, this interpolation should be accurate. The area between Steershead and Roosevelt Island is a site with strong discontinuities in flow speed. Here the RIGGS flowlines must be interpreted carefully, and can only be used for comparisons to flow stripes close to the RIGGS sites which have measured ice velocities, such as the previously mentioned area A. The difference between flowlines and flow stripes in this area suggests that the ice has begun spreading westward into the middle shelf in the recent past.

The same difficulty exists to the east of Roosevelt Island, where Figure 4 shows discordance between the RIGGS flowlines and flow stripes, but only one RIGGS site with directly measured velocity is available. The limited data from the RIGGS flow field cannot be used to definitively identify a change in ice flow in this area.

\section{FLOW HISTORY OF ICE STREAMS A AND B}

Two ice-shelf features figure prominently in the flow record of Ice Streams A and B: the paired tracks of rifts downstream of Crary Ice Rise and the large, bowed flow-stripe pattern west of the ice rise. Each of these has been reported and interpreted earlier (Jezek, 1984; Casassa and Turner, 1991). We present a linked hypothesis for the flow history responsible for their formation.

Figure 5 shows an enlargement of the two parallel rift tracks downstream of Crary Ice Rise. There are four distinct patterns to the rifting, two along each track, with a change in the pattern on each side occurring approximately $300 \mathrm{~km}$ downstream of the ice rise. Along the western track, the more recent pattern consists of large rifts forming in the lee of Crary Ice Rise which are progressively rotated counterclockwise. The observed degree of rotation is much larger than, and opposite in sense to, the rotation which would form in the present flow field, as illustrated by the pattern of 100 year markers in the figure. The older downstream portion of this track has a different character, with more subdued surface expression of infrequent large rifts rotated nearly parallel to the direction of flow. There is only a single intermediate rift at the transition $\left(80^{\circ} \mathrm{S}, 180^{\circ} \mathrm{W}\right)$, indicating this change in character occurred rapidly.

The eastern rift track can be traced back to the region east of Crary Ice Rise. The pattern of rifts is less regular than in the adjacent western rift track, but shows similar amounts of rotation. The eastern track also changes character $300 \mathrm{~km}$ downstream from Crary Ice Rise. At this point, the rifts become much longer and then transform downstream to a more diffuse pattern that nearly disappears at the ice-shelf front. When viewed in detail in Landsat imagery, this final
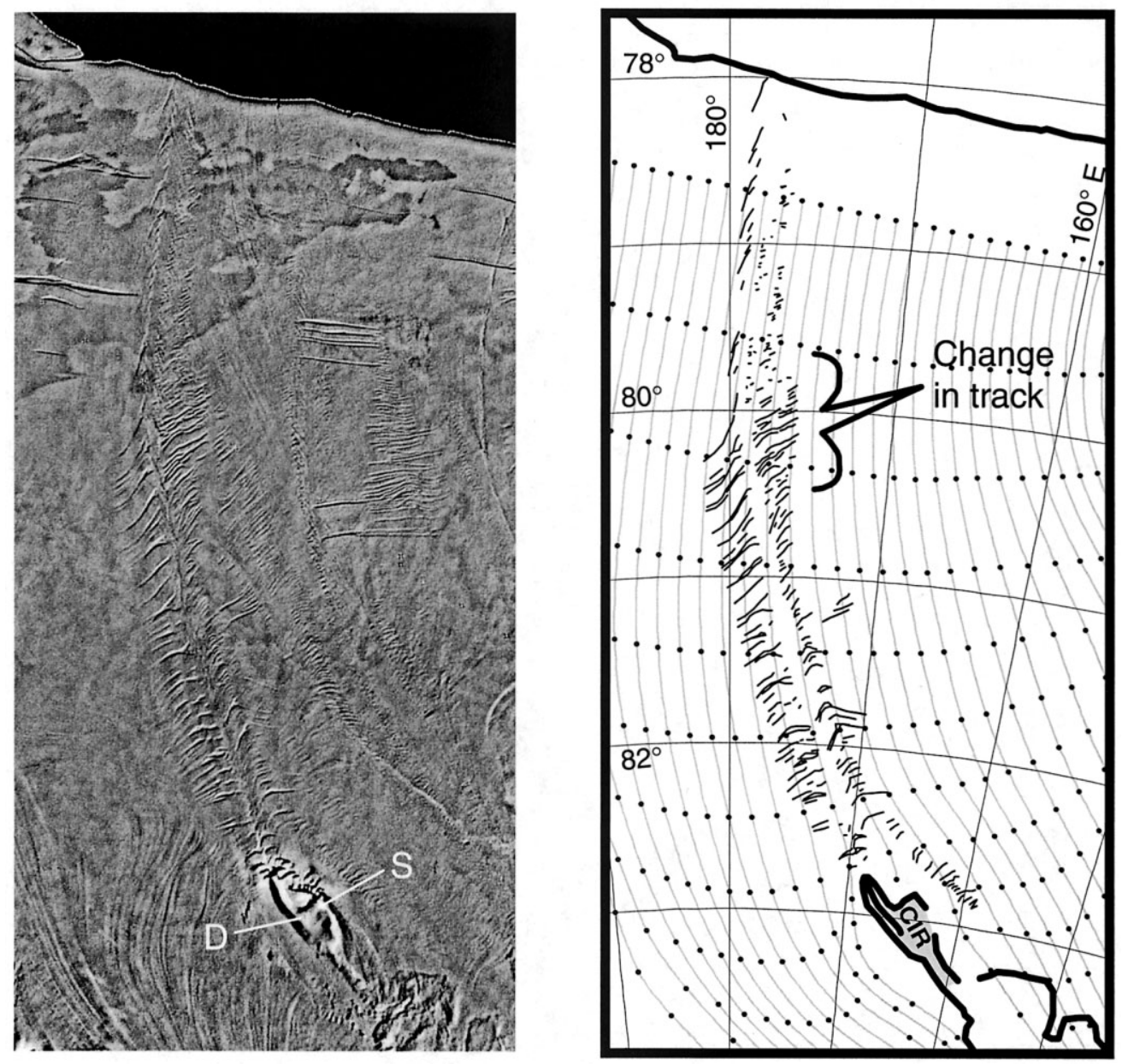

Fig. 5. Crary Ice Rise (CIR) and its downstream rift tracks. The tracks are produced by rifting on either side of the downstream end of Crary Ice Rise, and by an incomplete closure of the shelf ice on the downstream end. The image on the left is extracted directly from Figure 1, while the drawing on the right shows the rifts that we would interpret as coming from the downstream end of Crary Ice Rise, with the RIGGS flowlines for reference. D and S are the sites of Bindschadler and others' (1990) temperature profiles, discussed in the text. 
pattern appears very similar to the track of an ice-stream margin having entered the ice shelf, a texture seen most clearly in Landsat imagery of the floating margin of Ice Stream D.

Both rift tracks are oriented at an angle to the RIGGS flowlines. Jezek (1984) reported a similar observation from the trajectories of debris tracks detected with airborne radar soundings. We believe the rift tracks correspond to the debris tracks he was mapping.

An additional observation relevant to the interpretation of the flow history is the occurrence of a prominent sequence of rifts eastward of the twin rift tracks $\left(81^{\circ} \mathrm{S}, 175^{\circ} \mathrm{W}\right)$. This sequence is more oblique to the RIGGS flowlines and joins the eastern rift track at the location where the changes in the twin tracks occur (see Fig. 2b). What makes this track intriguing is that although the rifts are not always visible, the upstream extension of this sequence appears to meet the southern margin of Ice Stream C.

The continuous nature of the tracks, from Crary Ice Rise to the ice front, indicates that the ice rise, or some ancestral manifestation of it, has influenced ice flow over the entire time period recorded by the ice shelf downstream. The changes in the rift tracks record a radical change in flow. Applying the RIGGS flow field as a rough chronometer, the flow time from the ice rise to the ice front is roughly 700 years, with the radical change in flow occurring about 550 years ago.

Our interpretation of the flow situation prior to 550 years ago is that Ice Streams $\mathrm{A}$ and $\mathrm{B}$, or the ice from the regions now drained by these ice streams, flowed west of Crary Ice Rise and that Ice Stream C supplied the ice east of the eastern rift track. The rotation of the rifts indicates that, for a time, Ice Stream C flowed more rapidly than Ice Stream B. The "shear-margin-like" character of the downstream end of the eastern track suggests that the grounding line for Ice Stream C may have been located farther downstream, adjacent to the ice rise, at this time.

Flow stripes in the Ice Stream B ice adjacent to the Crary track and near the ice front are subtle and show little distortion. This ice does contain extremely large rifts parallel to the ice front (Fig. 2c). We attribute the formation of these rifts to recent stresses related to the proximity of the ice front, because the ends of these rifts are not rotated in the same manner as the rifts in the western track.

Estimates of the time since grounding of the ice rise based on vertical temperature profiles suggest basal freezing began about 580 years ago on the east side (site $\mathrm{S}$ in Fig. 5), while the ice to the west had been grounded for as long as 1100 years (site D in Fig. 5) (Bindschadler and others, 1990). More extensive grounding of Crary Ice Rise appears to coincide with the major change in flow as evidenced by the changes in the rift tracks. We interpret the dominant change in flow which occurred at this time to be a sustained eastward migration of the southernmost margin of Ice Stream C. The widening of Crary Ice Rise may have been produced by this change in flow. As the northern portion of Ice Stream B began to flow around the eastern side of Crary Ice Rise, Ice Stream C's margin would have moved farther eastward. The rotation of the rifts in the western track suggests that flow west of the ice rise was still slower than on the east side. In addition, the misalignment of the twin rift tracks with modern RIGGS flowlines supports the hypothesis that, during this period, flow east of Crary Ice Rise was more vigorous relative to the flow west of the ice rise, when compared with the present day.

The second prominent feature in the Ice Stream A/B flow is the large bowed pattern, or bulge, in the flow stripes west of Crary Ice Rise (Fig. 6). This bulge has been previously described as a "loop" in the flow stripes, interpreted to have been caused by incorporation of part of the ridge between Ice Streams A and B into the ice shelf (Casassa and Turner, 1991) and, in a later interpretation, to represent an increase in discharge of Ice Stream A relative to Ice Stream B at least 1000 years ago (Casassa, 1993).

The data-cumulated AVHRR image composite used here reveals new detail for this feature. The interior of the bulge contains flow stripes, and the disturbance represented by the bulge extends far downstream and upstream. These characteristics constrain its origin and make the hypothesis of a ridge-ice origin unlikely.

There are a number of other characteristics of the bulge flow stripes which are now visible. To the west of the bulge, flow stripes are undisturbed. This requires that the event
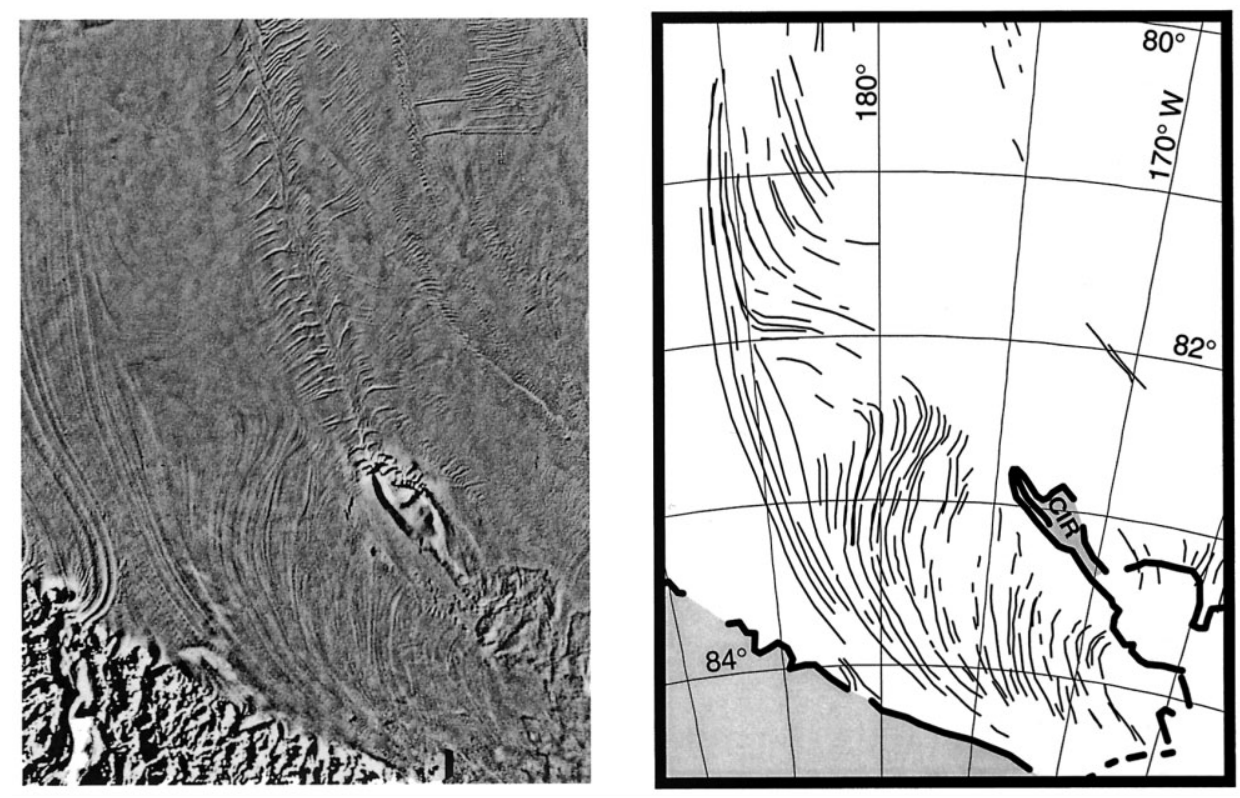

Fig. 6. The "bulge" in flow stripes to the west of Crary Ice Rise (CIR) that was originally identified by Casassa and Turner (1991). The image on the left is a detail of Figure 1, while the drawing on the right is an interpretation of the flow stripes visible in that image. 
forming the bulge occur upstream of the point where the undisturbed ice enters the ice shelf, i.e. upstream of about $160^{\circ} \mathrm{W}$ (see Fig. 1). Another important feature is that the flow stripes at the downstream end of the bulge $\left(82^{\circ} \mathrm{S}\right.$, $175^{\circ} \mathrm{E}$ ) turn sharply, suggesting that the event was sudden and incident from the south. Finally, flow stripes upstream of the bulge are observed to persist at high angles to the present flow direction. Also relevant is the fact that the downstream boundary of the bulge coincides with a steep gradient in ice thickness and that this plug of thicker ice continues upstream to Ice Streams A and B (Albert and Bentley, 1984).

We suggest that the bulge was formed by a massive influx of ice from the vicinity of Ice Stream A. The event is marked by the sharp bend in the flow stripes noted above, but its effect also extended to flow stripes $100 \mathrm{~km}$ downstream. The downstream ice must have been floating, or only slightly grounded, in order to have been influenced over such a great distance. The influx of ice may have been sufficient to have caused the grounding of, or to have more firmly grounded, the ice within the bulge.

We believe this event was responsible for the widening of the grounded part of Crary Ice Rise. Our interpretation of the flow stripes both downstream and upstream of the bulge is that they represent a continuation of the set of bowed flow stripes which define the bulge, but that the stripes farthest from the influx event (at the "top" of the bulge) were truncated as the ice flowed around both sides of Crary Ice Rise. A consequence of this interpretation is that ridge $\mathrm{B} / \mathrm{C}$ could not at this time have been connected to Crary Ice Rise (as a flow boundary between Ice Streams B and C) because the flow stripes at the "top" of the bulge were pushed northward of where the extended ridge would have had to exist.

One poorly reconciled observation is the bending of flow stripes upstream of the bulge. The most upstream of this set are difficult to resolve in the AVHRR image, but SPOT imagery shows that the distorted set is overprinted by a set of flow stripes (forming in the weakly grounded ice of the ice plain) which are aligned with present flow (Bindschadler, 1993).

To estimate the timing of the bulge formation, we apply the RIGGS velocities to the distance between the present bulge position and the entrance of Ice Stream A into the ice shelf (essentially the position across flow from the gap between ridge $\mathrm{B} / \mathrm{C}$ and Crary Ice Rise). Ages in the range 500-600 years ago result, but dating is uncertain in this region due to the large changes in flow that have occurred on both century and decadal time-scales. It is unlikely this event occurred more recently, as it would have had an effect on the rift tracks formed by Crary Ice Rise. We believe that this event was simultaneous with the events responsible for the changes seen in the rift tracks. Forcing a part of Ice Stream B to the east of the ice-rise area would have led to the lateral migration of the southern margin of Ice Stream C. In a later section, the possible influence of these connected events on the flow of Ice Stream C is discussed.

\section{EVOLUTION OF THE B/C GONFLUENGE}

Figure 7 provides a detailed look at the signature of the neargrounding-line interaction between Ice Streams B and C. It is possible to follow the last active southern shear margin of Ice Stream C onto the ice shelf, where it joins the track of an old northern shear margin of Ice Stream B. The joined margins continue down-flow for several hundred kilometers across the ice shelf, unbroken in spite of the fact that neither of the shear margins is currently active. The Ice Stream C margin is inactive because of the shutdown of the ice stream (discussed below), while the Ice Stream B margin is inactive because of a recent shift in margin position to the west.

The imagery appears to indicate that the northern margin of Ice Stream B is still in the process of establishing itself at its new location. Note that ridge $\mathrm{B} / \mathrm{C}$, which was bounded by two ice streams, has as a downstream record the trace of shear margins, rather than a record of rifts like those that form the Crary Ice Rise tracks. However, as the new margin of Ice Stream B establishes itself, several large rifts have formed. It appears that the shearing that is accommodated in an active shear margin as it is carried out on to the shelf prevents the process of rifting that flow past the end of a stationary object would otherwise cause. This may be due to the presence of softer (warmer and highly sheared) ice in the established shear margins, and the lack of soft ice where the new margin is forming.

\section{THE SHUTDOWN OF ICE STREAM G}

Another profound disturbance in the flow patterns of the ice streams in the last few hundred years has been the shutdown of Ice Stream C. This was originally recognized from buried crevasses along the downstream portion of the southern margin. Burial depths indicated that this margin ceased rapid shearing $130 \pm 25$ years prior to the depth measurement (about 140 years ago at the time of writing; see Bentley and others, 1985; Shabtaie and Bentley, 1987; Retzlaff and Bentley, 1993). However, recent satellite imagery and additional fieldwork has shown that the northern margin of Ice Stream C has had several incarnations, shifting position by $30-40 \mathrm{~km}$ to the south during a series of events leading to the final shutdown (Jacobel and others, 2000). A crude timing of this shift is available from flow modeling of the south flank of Siple Dome, indicating that it occurred 300-500 years ago (Jacobel and others, 2000), although it is likely that the changes have been small (cf. Nereson and others, 1998). Elevation differences between an earlier stranded section and the last active part of Ice Stream C and measured accumulation rates for the area (Bindschadler and others, 1988) are consistent with this timing. The shutdown of Ice Stream C may have been protracted, with the recent termination of shearing along the southern margin only the final act.

In Figures 7 and 8 we examine additional information recorded on the Ross Ice Shelf regarding the shutdown of Ice Stream C. Three groups of features are relevant. A group of flow stripes lead from the grounding line to Steershead ice rise and terminate there; these show a progressively increasing bend to the right, with the greatest arcs involving the southwestern stripes. Just downstream from this area, the few remaining flow stripes not truncated into Steershead splay out over a broad area containing numerous crevasses with various orientations. Farthest downstream, a more organized wedge-shaped pattern of larger rifts occurs, oriented transverse to flow, and decreasing in length as one proceeds downstream.

The RIGGS project estimated that ice in the Steershead feature was not moving, and a more recent view based on radar altimetry (Bamber and Bentley, 1994) strongly suggests that this feature is firmly grounded at present. The 


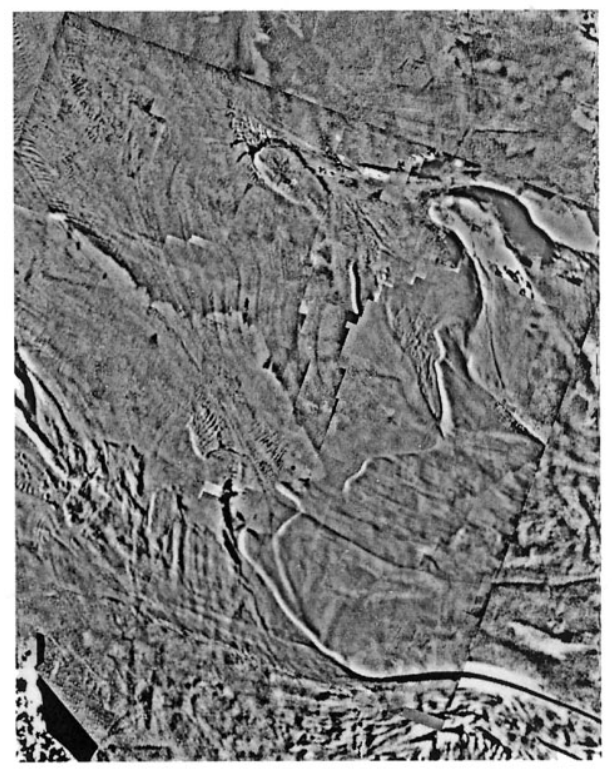

a

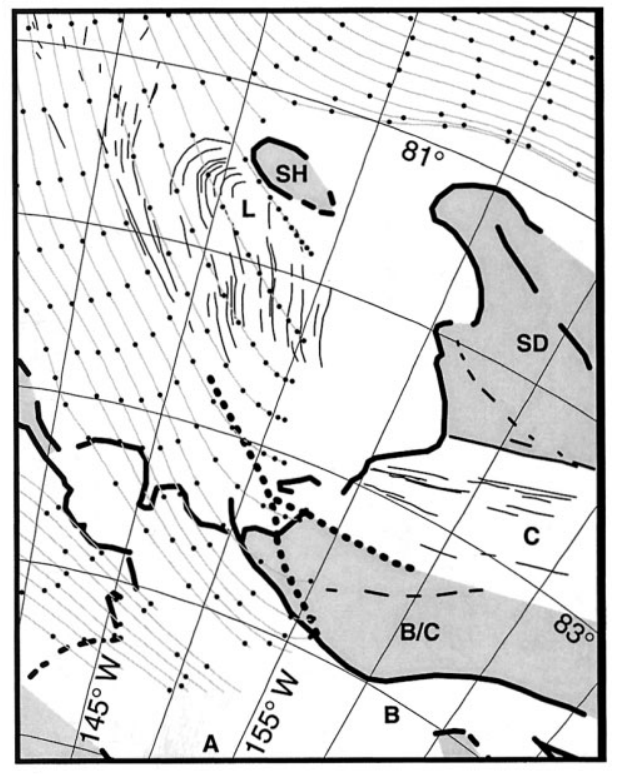

b

Fig. 7. (a) A second data-cumulated image of the mouth of Ice Stream C, inset into the image from Figure 1. The second image shows several features more clearly, due to a different illumination geometry. (b) Interpretation of the features visible in this imagery. Heavy dashed lines mark the former shear margins of Ice Streams B and C, and their trace out on the ice shelf. Two lighter dashed lines show locations of older potential margins of Ice Stream C. The light grey flowlines and 100 year displacement markers are from the RIGGS flow field ( see Fig. 2d) (note that these flowlines are not well constrained near the grounding line). The flow stripes shown in the right frame are from Figure $2 a$. The heavy continuous line shows the location of the grounding line (dashed where questionable) and active shear margins. The area labeled " $L$ " is the location of the loop in flow stripes associated with the grounding of Steershead (SH). Siple Dome (SD) is labeled.

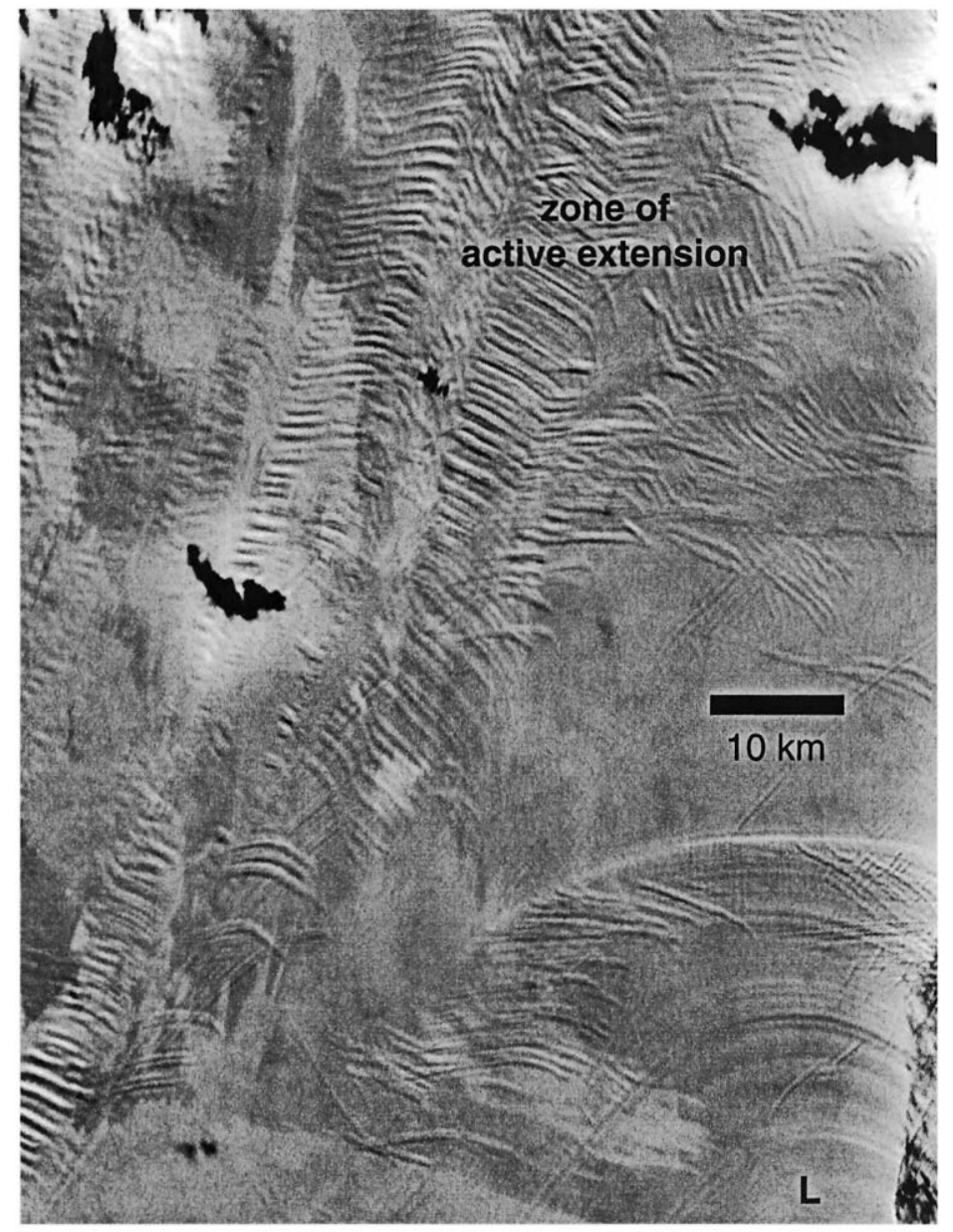

a

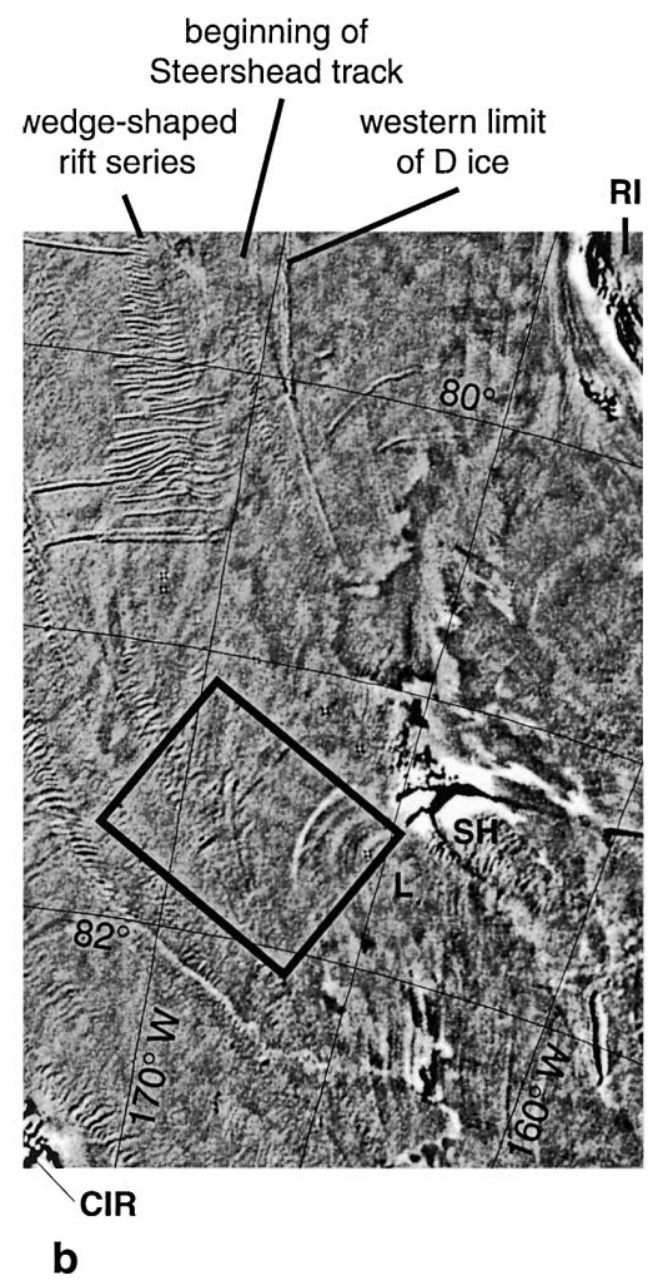

beginning of

Fig. 8. (a) Detail from a Landsat TM image, showing the extensive crevassing in the area we interpret as actively extending. (b) An image extracted from Figure 1, showing Steershead (SH) and the Ice Stream C flow-stripe loop (L). The box outlines the location of the Landsat detail shown in ( a). Roosevelt Island (RI) and Crary Ice Rise (CIR) are labeled. 
presence of flowlines truncated into the southern side of Steershead implies that at one time the ice comprising the ice rise must have been part of the outflow of Ice Stream C. The relatively recent origin (grounding) of Steershead is supported by the observation that the crevasse set associated with the feature is relatively short, as noted by Jezek (1984), and confirmed by this imagery. The northern limit of the track visible in the image is about 350 years downstream of Steershead in the RIGGS flow field, and is about $5 \mathrm{~km}$ west of the edge of ice from Ice Stream D, indicating that the ice rise is contained within ice that flowed out of Ice Stream C. For most of its length, the track downstream of Steershead is composed of faint, short crevasses. Only within the most recently formed $25 \mathrm{~km}$ of this track do the crevasses appear similar to the rifts on either side of Crary Ice Rise. We suggest that Steershead ice rise was an ice rumple area (i.e. grounded but not stagnant) in the past and became stagnant only recently. The grounding of Steershead ice rise may have been the result of thickening initiated when Ice Stream B ice was forced around the east side of Crary Ice Rise. The initial grounding may thus have followed the formation of the bulge but predated the final shutdown of Ice Stream C.

From model results, MacAyeal (1989) found that ice-thickness changes related to a shutdown of Ice Stream C would be confined within a few hundred kilometers of the grounding line. Because of the grounding of Steershead at about the start of the shutdown, much of the thinning appears to have been displaced downstream. Figure $8 \mathrm{a}$ is a portion of a Landsat TM image of the area downstream of Steershead ice rise and the flow-stripe loop attached to it. The image shows, at better resolution than the AVHRR composite, complex crevasse sets with many different orientations. This pattern, and the splaying of flow stripes mentioned above, suggests that this area is actively extending both along and across flow. Ice thickness in this area is tens of meters less than on either side (Bentley and others, 1979; Bamber and Bentley, 1994).

In addition to the recent thinning, Figure $8 \mathrm{~b}$ shows a series of larger rifts oriented transverse to flow just downstream of the actively extending area. At their downstream limit, these rifts are relatively short, just a few kilometers long, but their length increases upstream to $50 \mathrm{~km}$ near the area of active extension. Within this zone, the few flow stripes that may be traced are oriented parallel to the Ice Stream D flow stripes, unlike those in the actively extending region. Extension in this area was likely just downstream of, and coincident in time with the formation of, Steershead ice rise and the flow-stripe loop. The form of extension may have changed from these transverse rifts to the chaotic crevassing of the actively extending region, indicating a continuing accommodation of the shutdown.

\section{GONTINUED EVOLUTION OF WEST ANTARCTIC ICE STREAMS}

Measurements on the ice shelf during the second half of the 20th century confirm that flow variability is continuing. Where mass balance has been determined, imbalance is common. The largest imbalances reported on the ice shelf are in the vicinity of Crary Ice Rise (Bindschadler and others, 1989, 1993). Downstream of the ice rise, the pattern of rift formation appears to have undergone a transformation in the past few decades. The most recent rifts extend uninterrupted across the area previously forming the two rift tracks discussed above (Bindschadler and Vornberger, 1998).

Ice Streams B and C continue to change. In a previous section we described the confluence of Ice Streams B and C as a junction that is continuous with the features downstream on the ice shelf, in spite of the fact that both shear margins were presently inactive. The present active margin of Ice Stream B is west of this older margin, and is actively moving back to the north in the most recent analysis, which shows that the active margin has moved northward $4 \mathrm{~km}$ and that the western tip of ridge $\mathrm{B} / \mathrm{C}$ has eroded $14 \mathrm{~km}$ over 40 years (Bindschadler and Vornberger, 1998).

Accompanying the shifts in margin position are dramatic changes in speed. Ice Stream C's stagnation has already been discussed. More recently, a 50\% deceleration of ice upstream of Crary Ice Rise over 25 years has been inferred (Bindschadler and Vornberger, 1998). If these faster speeds were widespread, ages of events estimated using the RIGGS flow field would be too old.

Some debate remains on whether Ice Stream B's grounding line is advancing with substantial ice-shelf thickening or retreating since the early measurements of the ice shelf made in 1958/59 during the International Geophysical Year (Hübinger and others, 1992; Bindschadler, 1993). Data-cumulated AVHRR imagery has sufficient resolution to show the grounding-line position, so future monitoring is possible to settle the debate. What is not disputed is that this area continues to evolve rapidly. On the ice streams, speed, width and thickness have all been observed to be changing, ensuring that the variability recorded in the composite AVHRR image is ongoing.

\section{IGE OF UNGERTAIN ORIGIN}

As noted in a previous section, there is a region of ice near the ice front that is of uncertain provenance ("??" in Fig. 2c). We present two scenarios for the possible origin of that ice. Two aspects of the surface character bear on the origin of this area: the bounding shear and rift traces, and the orientation of the flow stripes within it. As noted in the Crary rift tracks discussion, the eastern track shows a distinct change in character along its length. Near the ice front, the eastern track appears to have formed as a shear margin; upstream the rifts appear to have formed due to flow past an ice rise. Flow-stripe orientation within the "??" section trends northwest-southeast, at about $20^{\circ}$ to the margin traces and flow stripes on either side. The presence of this ice at the ice front indicates that changes in ice-discharge patterns were occurring nearly 1000 years ago, when this ice would have been near the present location of the grounding line.

In one possible scenario, the "??" ice is derived from an earlier, wider incarnation of Ice Stream C whose outflow channel extended from the north side of Crary Ice Rise to the south flank of Siple Dome. At this time (prior to $\sim 700$ years BP in the RIGGS field) no Ice Stream B ice crossed the line linking Crary Ice Rise to ridge $\mathrm{B} / \mathrm{C}$. The more southwestward flow of Ice Stream $\mathrm{C}$ ice in this earliest proposed picture is preserved in the present-day trend of flow stripes in the "??" section.

At about 700 years BP, a northward margin shift of Ice Stream C isolated a section of the ice, and the new southern margin passed this ice to the north. The older, more southerly margin position may be preserved as a slope break 
along the northwestern side of ridge $\mathrm{B} / \mathrm{C}$, south of the more recent, known southern margin of Ice Stream C.

At approximately 550 years BP, a significant, abrupt increase in flux from either the southern part of Ice Stream B or the entirety of Ice Stream A distorted flow stripes at or near the grounding line of present-day Ice Stream A. We believe that this flux increase prompted a major reorganization of flow around Crary, causing the previously stagnant ice from Ice Stream C to begin to flow northward, and initiating flow of northern Ice Stream B ice to the north side of Crary Ice Rise. This also marks a change in the nature of deformation around the northern side of the ice rise, from one similar to a grounded shear margin to the present-day pattern of larger transverse rifts. This produces the change in the character of the eastern rift track.

The alternative to this scenario is to attribute the "??" ice to Ice Stream B. This allows the provenance boundaries from each section in Figure $2 \mathrm{a}$ to be more or less parallel, representing nearly constant relative discharge fluxes from each stream. However, this scenario fails to explain the apparent shear margin on the western side of the "??" ice, the orientation of the flow stripes within that ice, and the extensive rifting in the eastern track just upstream of the change in character. We favor the first scenario because of its ability to explain these observed features.

\section{CONCLUSIONS}

We have presented a complex set of flow-related features identified in an enhanced composite AVHRR image of the Ross Ice Shelf. The combination of these features, visible on the shelf's surface, with earlier surface and satellite work allows for interpretation of the flow history of the ice streams and ice shelf. Four major events can explain most of the observations made in this paper, as well as provide a possible mechanism for generation of the features in the "??" ice.

As illustrated in Figure 9, the major events in this scenario are:

1. A hypothesized jump in the position of the southern margin of Ice Stream C to the north, separating it from an early Crary Ice Rise prior to 700 years BP. This jump stranded the "unknown" ice upstream of Crary Ice Rise.

2. A pulse of increased ice outflow from the Ice Stream A and B system which pushed ice northward around the east side of Crary Ice Rise about 550 years BP. This pulse displaced the "??" ice, which was either pushed across the grounding line or had thinned enough to float.

3. A southward shift in the northern margin of Ice Stream $\mathrm{C}$, and a commensurate decline in flux beginning in the northern portion of the Ice Stream $\mathrm{G}$ outflow about 350 years BP. This event may correspond to the beginning of grounding at Steershead; the initial grounding may have been the result of thickening caused by event 2 .

4. A final cessation of the rapid flow of Ice Stream $\mathrm{C}$ about 140 years ago, with associated effects still propagating across the central ice shelf.

In addition to this flow history, new observations about the Ross Ice Shelf may be extracted from this imagery:

1. Flow-stripe deviation from the RIGGS flow field to the southwest of Roosevelt Island, due to a recently grounded region.

2. A change in the northern margin of Ice Stream B. The downstream trace of the boundary separating ice derived from Ice Streams B and C does not coincide with the currently active northern margin of Ice Stream B, implying that the current margin is very young, and also implying that a scar on ridge $\mathrm{B} / \mathrm{C}$ must have been the former northern margin of Ice Stream B for an extended period of time.

3. A very short downstream track of large open rifts which indicate a recent stagnation of Steershead ice rise.

4. Bending of flow stripes from the grounding line of Ice Stream $\mathrm{C}$ into a loop which truncates against the southwest boundary of Steershead ice rise.

5. A shift of much of the active extension from the shutdown of Ice Stream G to downstream of Steershead ice rise, rather than near the grounding line of the ice stream.

6. A change in the twin rift tracks downstream of Crary Ice Rise. Over the northernmost (oldest) third, the eastern track exhibits features more like a shear margin (fainter, shorter crevasses at several oblique orientations), while the rest is characterized by large rifts oriented across flow. These rift tracks extend to the ice front, indicating that the ice rise has existed throughout the record preserved by the shelf.

7. Details about the large bulge in the flow stripes northwest of Crary, which is bounded on the west by flow stripes that are undisturbed. To the east, and for an extended distance both upstream and downstream of the bulge center, flow stripes are bent eastward, indicating that the event leading to bulge formation occurred from the south and displaced ice which must have been either weakly grounded or floating.

What is least certain from the above interpretations is the occurrence of a speculative event which would have isolated the section of ice near the ice front with flow stripes oriented northwest/southeast, at a distinct angle to the ice on either side of its boundaries. Because of its age and position near the ice front, this ice has an uncertain source. In addition, there is uncertainty in the timing of events, primarily because of the record of variable discharge into the ice shelf. Use of the RIGGS flow field to date features on the ice shelf works strictly only for a system in steady state. Better characterization of the changes taking place on the ice shelf today would allow more confident use of the flow field in the recent past; improvements in timing beyond this will be difficult. It is clear, however, that the features identified in the AVHRR image composite reveal a complex history, showing that ice discharge from the West Antarctic ice sheet into the Ross Ice Shelf has been variable for at least the last millennium.

\section{REFERENGES}

Albert, D. G. and C. R. Bentley. 1984. Seismic studies on the grid-eastern half of the Ross Ice Shelf: RIGGS III and RIGGS IV. In Hayes, D. and C. R. Bentley, eds. The Ross Ice Shelf: glaciology and geophysics. Washington, DC, American Geophysical Union, 87-108. (Antarctic Research Series 42.)

Alley, R. B. and I. M. Whillans. 1991. Changes in the West Antarctic ice sheet. Science, 254(5034), 959-963.

Bamber, J. and C. R. Bentley. 1994. A comparison of satellite-altimetry and ice-thickness measurements of the Ross Ice Shelf, Antarctica. Ann. Glaciol., 

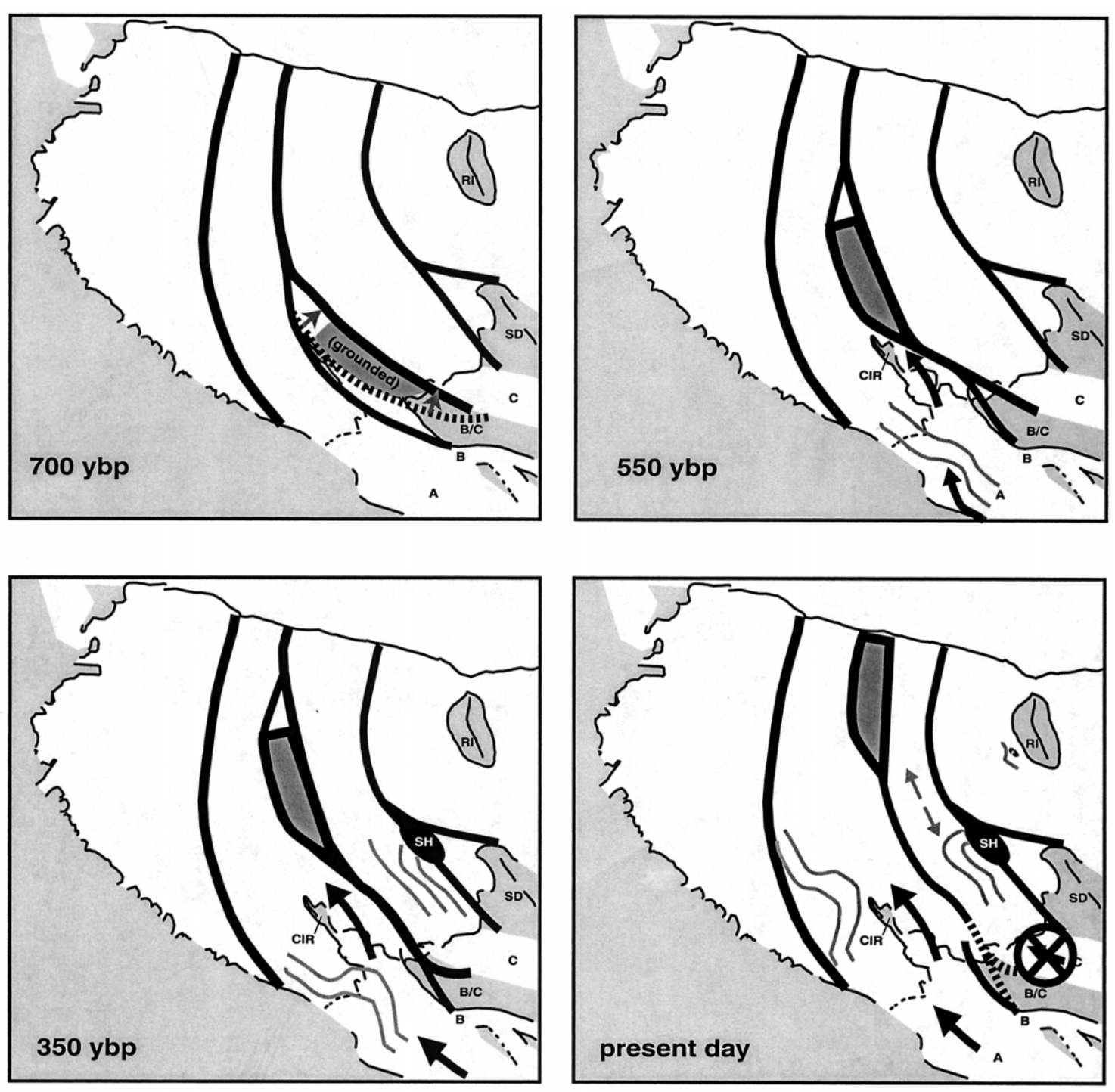

Fig. 9. One possible ice-flow history that would result in the present configuration of flow stripes and rifts on the ice shelf. The events which drive this interpretation are discussed in the text. Roosevelt Island (RI), Steershead ice rise (SH), Crary Ice Rise (CIR), Siple Dome (SD) and ridge B/C are labeled, as are Ice Streams $A-C$.

20,357-364.

Bentley, C. R. 1984. The Ross Ice Shelf Geophysical and Glaciological Survey (RIGGS): introduction and summary of measurements performed. In Hayes, D. and C. R. Bentley, eds. The Ross Ice Shelf: glaciology and geophysics. Washington, DC, American Geophysical Union, 1-20. (Antarctic Research Series 42.)

Bentley, C. R., J.W. Clough, K. C. Jezek and S. Shabtaie. 1979. Ice-thickness patterns and the dynamics of the Ross Ice Shelf, Antarctica. F. Glaciol., 24(90), 287-294.

Bentley, C. R., S. Shabtaie, D. G. Schultz and S. T. Rooney. 1985. Continuation of glaciogeophysical survey of the interior Ross Embayment: summary of 1984-1985 field work. Antarct. F. U.S., 20(5), 63-64.

Bindschadler, R. 1993. Siple Coast Project research of Crary Ice Rise and the mouths of Ice Streams B and C, West Antarctica: review and new perspectives. F. Glaciol., 39(133), 538-552.

Bindschadler, R. A. 1998a. Future of the West Antarctic ice sheet. Science, 282(5388), 428-429.

Bindschadler, R. 1998b. Monitoring ice sheet behavior from space. Rev. Geophys., 36(1), 79-104.

Bindschadler, R. A. and P. L. Vornberger. 1990. AVHRR imagery reveals Antarctic ice dynamics. EOS, 71 (23), 741-742.

Bindschadler, R. and P. Vornberger. 1998. Changes in the West Antarctic ice sheet since 1963 from declassified satellite photography. Science, 279(5351), 689-692.

Bindschadler, R. A., S. N. Stephenson, E. P. Roberts, D. R. MacAyeal and D. R. Lindstrom. 1988. Data report for the Siple Coast Project. NASA Tech. Memo. 100708.

Bindschadler, R. A., E. P. Roberts and D. R. MacAyeal. 1989. Distribution of net mass balance in the vicinity of Crary Ice Rise, Antarctica. F. Glaciol., $35(121), 370-377$.

Bindschadler, R. A., E. P. Roberts and A. Iken. 1990. Age of Crary Ice Rise,
Antarctica, determined from temperature-depth profiles. Ann. Glaciol., 14, 13-16.

Bindschadler, R., P. L. Vornberger and S. Shabtaie. 1993. The detailed net mass balance of the ice plain on Ice Stream B, Antarctica: a geographic information system approach. f. Glaciol., 39(133), 471-482.

Casassa, G. 1993. Features on the Ross Ice Shelf, Antarctica, studied with AVHRR satellite imagery and by modeling. (Ph.D. thesis, Ohio State University.)

Casassa, G. and J. Turner. 1991. Dynamics of the Ross Ice Shelf. [Abstract.] EOS, 72 (44), Supplement, 473, 481.

Casassa, G. and I. M. Whillans. 1994. Decay of surface topography on the Ross Ice Shelf, Antarctica. Ann. Glaciol., 20, 249-253.

Crabtree, R. D. and C.S. M. Doake. 1980. Flow lines on Antarctic ice shelves. Polar Rec., 20 (124), 31-37.

Dowdeswell, J. A. and N. F. McIntyre. 1987. The surface topography of large ice masses from LANDSAT imagery. F. Glaciol., 33(113), 16-23.

Echelmeyer, K. A. and W. D. Harrison. 1999. Ongoing margin migration of Ice Stream B, Antarctica. F. Glaciol., 45(150), 361-369.

Ferrigno, J.G. and 7 others. 1994. Landsat TM image maps of the Shirase and Siple Coast ice streams, West Antarctica. Ann. Glaciol., 20, 407-412.

Gudmundsson, G. H. 1996. A mechanism for the generation of flow stripes on ice streams. CRREL Spec. Rep. 96-27, 30-33.

Hambrey, M. J. and J. A. Dowdeswell. 1994. Flow regime of the Lambert Glacier-Amery Ice Shelf system, Antarctica: structural evidence from Landsat imagery. Ann. Glaciol., 20, 401-406.

Hübinger, S., S. Shabtaie and C. R. Bentley. 1992. Comparison of TRANSIT satellite and IGY surface elevations on Ross Ice Shelf: thinning and retreat of the "ice plain". [Abstract.] EOS, 73(43), Supplement, 179.

Hughes, T. J. 1997. Ice sheets. New York, etc., Oxford University Press.

Jacobel, R.W., T. A. Scambos, N. A. Nereson and C. F. Raymond. 2000. Changes in the margin of Ice Stream C, Antarctica. F. Glaciol., 46(152), 
$102-110$.

Jezek, K. C. 1984. Recent changes in the dynamic condition of the Ross Ice Shelf, Antarctica. 7. Geophys. Res., 89(B1), 409-416.

MacAyeal, D. R. 1989. Ice-shelf response to ice-stream discharge fluctuations: III. The effects of ice-stream imbalance on the Ross Ice Shelf, Antarctica. f. Glaciol., 35(119), 38-42.

Merry, C. J. and I. M. Whillans. 1993. Ice-flow features on Ice Stream B, Antarctica, revealed by SPOT HRV imagery. F. Glaciol., 39(133), 515-527.

Neal, C. S. 1979. The dynamics of the Ross Ice Shelf revealed by radio echosounding. 7. Glaciol., 24(90), 295-307.

Nereson, N. A., R. C. A. Hindmarsh and C. F. Raymond. 1998. Sensitivity of the divide position at Siple Dome, West Antarctica, to boundary forcing. Ann. Glaciol., 27, 207-214.

Orheim, O. and B. K. Lucchitta. 1988. Numerical analysis of Landsat Thematic Mapper images of Antarctica: surface temperatures and physical properties. Ann. Glaciol., 11, 109-120.

Reichenbach, S. E., D. E. Koehler and D.W. Strelow. 1995. Restoration and reconstruction of AVHRR images. IEEE Trans. Geosci. Remote Sensing, GE-33(4), 997-1007.

Retzlaff, R. and C. R. Bentley. 1993. Timing of stagnation of Ice Stream C, West Antarctica, from short-pulse radar studies of buried surface crevasses. 7. Glaciol., 39(133), 553-561.

Robertson, J. D. and C. R. Bentley. 1984. Seismic studies on the grid-western half of the Ross Ice Shelf: RIGGS I and RIGGS II. In Hayes, D. and C. R. Bentley, eds. The Ross Ice Shelf: glaciology and geophysics. Washington, DC, American Geophysical Union, 55-86. (Antarctic Research Series 42.)

Scambos, T. A. and R. A. Bindschadler. 1991. Feature maps of Ice Streams C, D and E, West Antarctica. Antarct. F. U.S., 26(5), 312-314.

Scambos, T. A., M. J. Dutkiewicz, J. C. Wilson and R. A. Bindschadler. 1992. Application of image cross-correlation to the measurement of glacier velocity using satellite image data. Remote Sensing Environ., 42(3), 177-186.

Scambos, T. A., G. Kvaran and M. A. Fahnestock. 1999. Improving AVHRR resolution through data cumulation for mapping polar ice sheets. Remote Sensing Environ., 69(1), 56-66.

Shabtaie, S. and C. R. Bentley. 1987. West Antarctic ice streams draining into the Ross Ice Shelf: configuration and mass balance. 7. Geophys. Res., 92(B2), 1311-1336. (Erratum: F. Geophys. Res., 1987, 92(B9), 9451.)

Thomas, R. H., D. R. MacAyeal, D. H. Eilers and D. R. Gaylord. 1984 Glaciological studies on the Ross Ice Shelf, Antarctica, 1973-1978. In Hayes, D. and C. R. Bentley, eds. The Ross Ice Shelf: glaciology and geophysics. Washington, DC, American Geophysical Union, 21-53. (Antarctic Research Series 42.)

\section{APPENDIX A}

\section{DATA-PROCESSING STEPS}

For each AVHRR image listed in Table 1, channels 1 and 2 are extracted from the swath data and modified to reduce the effect of the AVHRR point-spread function (Reichenbach and others, 1995). They are then combined into a first principalcomponent image. This synthetic "channel" of the AVHRR swath is geolocated based on the orbital ephemeris data (including clock-drift correction), reprojected, and at the same time resampled to a smaller grid. For the Ross Ice Shelf image, the projection used is polar stereographic from the World Geodetic System (WGS84) ellipsoid, with the plane of projection parallel to the $70^{\circ} \mathrm{S}$ latitude line. Effects of topography are approximately corrected using the ETOPO5 digital elevation model (available from EROS Data Center, Sioux Falls, South Dakota). The projected image was resampled to a new grid of $150 \mathrm{~m}$ pixels, using a nearest-neighbor transformation; thus individual samples from the original AVHRR pixels are represented as fields of smaller pixels.

The ephemeris-based geolocation is accurate to only about $\pm 3 \mathrm{~km}$. Therefore, the reprojected images are not precisely co-registered. To align the images to the sub-pixel accuracy required for data cumulation, an image-to-image correlation routine is applied, matching surface features in
Table 1. AVHRR scenes used for Ross Ice Shelf data-cumulated image map

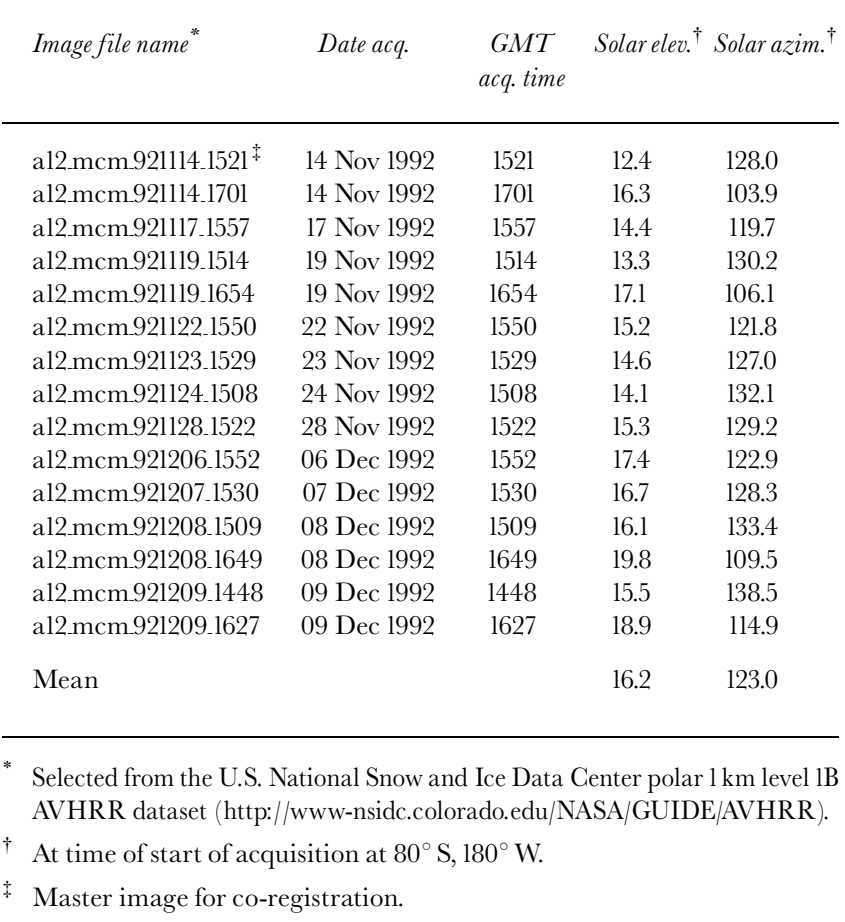

the images on the basis of the pattern of grey-scale values (Scambos and others, 1992). Surface features in the spatial range $0-15 \mathrm{~km}$ are enhanced by using a high-pass spatial filter prior to running the matching routine. Scenes are coregistered to a "master" image, selected on the basis of maximum clear-sky area and an imaging geometry close to the mean. Final registration is achieved by shifting the images to the best-match position at the new, smaller-pixel grid scale (i.e. about 0.125 pixels relative to the original image data pixels).

All the images contain at least a few clouds or sensor errors. Prior to combining the images, a mask is created by manually outlining these areas. The images are multiplied by their respective bit-map masks to create a scene of clearimage areas interspersed with zero-value areas (where the images were cloudy or noisy). Then both the images and the bit-map masks are summed. The data-cumulated image is derived by dividing the summed image by the summed bit-maps. Although 15 images were used in generating the data cumulation, the actual number of images contributing to any one area ranges from 4 to 11 .

Final processing steps are resampling to a pixel size appropriate to the actual resolution, and adjusting the histogram to enhance subtle features on the ice shelf. The images were processed as four-byte real data files until the last step, to preserve radiometric sensitivity.

In the final image, spatial resolution for areas having more than eight images contributing to them (i.e. most of the imaged area) have a true spatial resolution of approximately $800 \mathrm{~m}$. Radiometrically, the improvement is a factor of approximately four relative to a single-channel AVHRR image. This radiometric improvement is a combination of the improvement achieved using principal components and the cumulation of the PG images. 